\title{
Microsatellite loci for tUCUMã of Amazonas (ASTROCARYUM ACULEATUM) AND AMPLIFICATION IN OTHER ArecaceaE ${ }^{1}$
}

\author{
Santiago L. Ferreyra Ramos ${ }^{2}$, Jeferson L. Vasconcelos de Macêdo ${ }^{3}$, Maria T. Gomes \\ Lopes $^{4}$, Jacqueline S. Batista ${ }^{5}$, Kyara M. Formiga ${ }^{5}$, Perla Pimentel da Silva ${ }^{6}$, Antonio C. \\ Saulo-Machado ${ }^{7}$, And Elizabeth Ann Veasey 2,8 \\ ${ }^{2}$ Departamento de Genética, Escola Superior de Agricultura "Luiz de Queiroz" (ESALQ), Universidade de São Paulo (USP), CP \\ 83, CEP 13400-970, Piracicaba, São Paulo, Brazil; 32Embrapa Amazônia Ocidental, AM 010, CP 319, CEP 69048-660, Manaus, \\ Amazonas, Brazil; ${ }^{4}$ Faculdade de Ciências Agrárias, Universidade Federal do Amazonas (UFAM), CEP 60077-000, Manaus, \\ Amazonas, Brazil; ${ }^{5}$ Laboratório Temático de Biologia Molecular (LTBM), Laboratório de Fisiologia Comportamental (LFCE), \\ Coordenação de Biodiversidade (CBIO), Instituto Nacional de Pesquisas da Amazônia (INPA), CP 478, CEP 69060-001, \\ Manaus, Amazonas, Brazil; ${ }^{6}$ Centro de Energia Nuclear da Agricultura (CENA), Universidade de São Paulo, CP 96, CEP 13400- \\ 970, Piracicaba, São Paulo, Brazil; and ${ }^{7}$ Instituto de Ciências Biológicas, Universidade Federal do Amazonas (UFAM), CEP \\ 60077-000, Manaus, Amazonas, Brazil
}

- Premise of the study: Microsatellite loci were developed for tucumã of Amazonas (Astrocaryum aculeatum), and cross-species amplification was performed in six other Arecaceae, to investigate genetic diversity and population structure and to provide support for natural populations management.

- Methods and Results: Fourteen microsatellite loci were isolated from a microsatellite-enriched genomic library and used to characterize two wild populations of tucumã of Amazonas (Manaus and Manicoré cities). The investigated loci displayed high polymorphism for both A. aculeatum populations, with a mean observed heterozygosity of 0.498 . Amplification rates ranging from 50\% to 93\% were found for four Astrocaryum species and two additional species of Arecaceae.

- Conclusions: The information derived from the microsatellite markers developed here provides significant gains in conserved allelic richness and supports the implementation of several molecular breeding strategies for the Amazonian tucumã.

Key words: Amazon; Arecaceae; Astrocaryum aculeatum; microsatellites; tucumã.

Tucumã of Amazonas (Astrocaryum aculeatum G. Mey.) is a tropical palm found in western and central Brazilian Amazonia. The species is common in areas that are deforested or degraded under anthropogenic influence. Traditionally, the raw fruit is eaten by the local population; it is one of the most expensive fruits on the market in Manaus. The thin pulp of tucumã fruit is rich in starch, oil, and beta-carotene. The seeds and flesh can be pressed to extract edible oils for human consumption, and the dried cake residue is used as animal feed. However, the tucumã fruit market is supplied almost exclusively by natural harvesting, and the supply fluctuates both in

\footnotetext{
${ }^{1}$ Manuscript received 22 December 2011; revision accepted 5 August 2012.

The authors thank the Fundação de Amparo à Pesquisa do Estado do Amazonas (FAPEAM) for scholarships to S.L.F.R., P.P.S., and A.C.S.M.; the Financiadora de Estudos e Projetos (FINEP) and FAPEAM for funding the project CTIAFAM (Process 01.06.0380.04); the Conselho Nacional de Pesquisa e Desenvolvimento (CNPq) for funding the project BIOPALM (Process 553254/2005-7); and the Coordenação de Aperfeiçoamento de Pessoal de Nível Superior (CAPES)-Programa de Excelência Acadêmica (Proex) of the Departamento de Genética ESALQ-USP for supporting this research.

${ }^{8}$ Author for correspondence: eaveasey@usp.br
}

doi:10.3732/ajb.1100607 terms of fruit quality and quantity (Ramos et al., 2011; Lopes et al., 2012).

Within the genetic variability available in natural populations, genotypes with high fruit yield, good pulp consistency, and good taste can be selected (Schroth et al., 2004). There are two possible methods to increase fruit quality and quantity: (1) improving natural populations by in situ breeding and (2) using selected genotypes to develop commercial crops (Lopes et al., 2012). Increased demand in the marketplace and the high prices paid for the fruit have aroused increasing interest in developing tucumã as a commercial crop, mainly from farmers in the Manaus city region, but no selected material is available for creating plantations.

Genetic markers can allow the study of important issues in population genetics as well as ecological and evolutionary approaches (Ouborg et al., 2010). Microsatellite or simple sequence repeat (SSR) loci are widely employed in conservation genetics to estimate genetic variation, population structure, gene flow, demographic history, and hybridization events (Ouborg et al., 2010). In this study, we describe the development of 14 microsatellite loci used for the characterization of two populations of A. aculeatum. Additionally, the 14 microsatellite loci were tested for amplification in other Arecaceae species. Although Ramos et al. (2011) studied the mating system of one population of this species with SSR markers, the authors 
used heterologous primers developed for Bactris gasipaes Kunth. Therefore, this is the first report on specific SSR markers developed for $A$. aculeatum.

\section{METHODS AND RESULTS}

Genomic DNA extraction was conducted for all samples of A. aculeatum using a modified cetyltrimethylammonium bromide (CTAB) method (Doyle and Doyle, 1990). A microsatellite-enriched library for A. aculeatum was obtained using adapted protocols from Billotte et al. (1999). Genomic DNA samples were digested with $R s a \mathrm{I}$ and the resulting DNA fragments were linked to Rsa21 and Rsa25 adapters (IDT). The preamplified ligate DNA were obtained by PCR using Rsa21 primer and purified with the QIAquick PCR Purification Kit (QIAGEN, Germantown, Maryland, USA). DNA fragments containing putative markers were selected by hybridization with $(\mathrm{CT})_{8}$ and $(\mathrm{GT})_{8}$ repeats and biotin-linked probes, and recovered with streptavidin-linked particles (Streptavidin MagneSphere Paramagnetic Particles; Promega Corporation, Madison, Wisconsin, USA).

Selected amplified fragments were ligated into a pGEM-T Easy Vector (Promega Corporation) and transformed into eletrocompetent Escherichia coli TOP10 cells (Invitrogen, Carlsbad, California, USA) in an electroporator (Eppendorf, Hamburg, Germany). Transformed cells were cultivated onto Luria-Bertani (LB) agar containing $50 \mu \mathrm{g} / \mathrm{mL}$ IPTG and X-Gal to an overnight growth at $37^{\circ} \mathrm{C}$. Sufficiently separated white colonies were selected after overnight storage at $4{ }^{\circ} \mathrm{C}$ and transferred to 96 -well plates, with each well containing $200 \mu \mathrm{L} \mathrm{LB}$ medium amended with ampicillin $(100 \mu \mathrm{g} / \mathrm{mL})$. Cells were incubated at $37^{\circ} \mathrm{C}$ for $15-20 \mathrm{~h}$ and used for colony PCR amplification. A total of 96 positive clones were sequenced in both directions in an automated sequencer
ABI 3130xl Genetic Analyzer (Applied Biosystems, Foster City, California, USA) using T7 and SP6 primers and BigDye Terminator Cycle Sequencing Kit version 3.1 (Applied Biosystems). The sequences were analyzed, assembled, and edited with BIOEDIT 7.0.5 (Hall, 1999). Using the WebSat program (Martins et al., 2009), 28 suitable microsatellite regions of 96 nonredundant clone sequences were identified and used to design the primers. We considered dinucleotides with more than six repeats, trinucleotides with five or more repeats, tetranucleotides with four or more repeats, pentanucleotides with three or more repeats, and hexanucleotides with two or more repeats. An M13 sequence tail was added in the $5^{\prime}$ end of each forward primer following a labeling protocol (Schuelke, 2000). In this first step, 14 SSR loci were characterized. The microsatellite fragments were amplified using the Veriti Thermal Cycler (Applied Biosystems) in a total volume of $10 \mu \mathrm{L}$ per reaction, containing $10 \mathrm{ng}$ of genomic DNA template, $1.0 \mu \mathrm{L} 10 \times$ buffer, each dNTP at $200 \mu \mathrm{M}, \mathrm{MgCl}_{2}$ at $1.5 \mathrm{mM}$, forward and M13 label primer (FAM or NED) at $0.16 \mu \mathrm{M}$, reverse primer at $0.32 \mu \mathrm{M}, 1 \mathrm{U}$ of Taq DNA polymerase (Invitrogen), and $3.49 \mu \mathrm{L}$ milli-Q $\mathrm{H}_{2} \mathrm{O}$. PCR was carried out in two steps: the first consisted of denaturation $\left(68^{\circ} \mathrm{C}, 2 \mathrm{~min} ; 94^{\circ} \mathrm{C}, 30 \mathrm{~s}\right)$ followed by 30 cycles $\left(30 \mathrm{~s}\right.$ at $92^{\circ} \mathrm{C}, 35 \mathrm{~s}$ at the primer-specific annealing temperature [Table 1$], 30 \mathrm{~s}$ at $68^{\circ} \mathrm{C}\left[72^{\circ} \mathrm{C}\right.$ for $\mathrm{Aac} 07$ and Aac11]); the second step consisted of 15 cycles $\left(30 \mathrm{~s}\right.$ at $92^{\circ} \mathrm{C}, 30 \mathrm{~s}$ at $53^{\circ} \mathrm{C}$, $30 \mathrm{~s}$ at $72^{\circ} \mathrm{C}$ ) and a final extension at $72^{\circ} \mathrm{C}$ for $30 \mathrm{~min}$.

Amplification products were checked by electrophoresis on $1.5 \%$ agarose gels stained with GelRed (Biotium, Hayward, California, USA) in 1× TBE buffer ( $\mathrm{pH}$ 8.0). PCR products were visualized on an automated ABI 3130xl Genetic Analyzer (Applied Biosystems), and allele sizes were scored using ET-550 ROX size standard (GE Healthcare, Amersham, Buckinghamshire, United Kingdom) analyzed on GeneMapper version 4.0 software (Applied Biosystems). Polymorphisms for the 14 microsatellite loci were evaluated in 40 individuals of A. aculeatum collected in two natural populations in the state of Amazonas, Brazil, specifically in a forest fragment within the city of Manaus

TABLE 1. Characterization of microsatellite loci developed for Astrocaryum aculeatum in two populations from Amazonas, Brazil.

\begin{tabular}{|c|c|c|c|c|c|c|c|c|c|c|c|c|c|}
\hline \multirow[b]{2}{*}{ Locus } & \multirow{2}{*}{$\begin{array}{c}\text { GenBank } \\
\text { accession no. }\end{array}$} & \multirow[b]{2}{*}{ Repeat motif } & \multirow[b]{2}{*}{ Primer sequences $\left(5^{\prime}-3^{\prime}\right)^{\mathrm{a}}$} & \multirow[b]{2}{*}{$T_{\mathrm{a}}\left({ }^{\circ} \mathrm{C}\right)$} & \multirow{2}{*}{$\begin{array}{l}\text { Allele size } \\
\text { range (bp) }\end{array}$} & \multicolumn{4}{|c|}{ Manaus ${ }^{b}$} & \multicolumn{4}{|c|}{ Manicoréb } \\
\hline & & & & & & $N$ & $A$ & $H_{\mathrm{e}}$ & $H_{\mathrm{o}}$ & $N$ & $A$ & $H_{\mathrm{e}}$ & $H_{\mathrm{o}}$ \\
\hline $\mathrm{Aac} 01$ & GF111927 & $(\mathrm{ATCACT})_{2}$ & $\begin{array}{l}\text { F: <FAM>CACATGGTTCCTCCTCGTTC } \\
\text { R: GCGAAAGGGTATAGTCAGCG }\end{array}$ & 60 & $332-362$ & 19 & 2 & 0.102 & 0.105 & 20 & 1 & 0.000 & 0.000 \\
\hline $\mathrm{Aac0} 2$ & GF111928 & $(\mathrm{GCCATG})_{2}$ & $\begin{array}{l}\mathrm{F}: \quad<\text { NED>CGATTTGAGTCCGATGTG } \\
\mathrm{R}: \text { GCAGTTGTGTGTCTGGTTCT }\end{array}$ & 60 & $282-342$ & 19 & 2 & 0.309 & 0.368 & 20 & 2 & 0.481 & 0.750 \\
\hline $\mathrm{Aac} 03$ & GF111929 & $(\mathrm{TCCTAC})_{2}$ & $\begin{array}{l}\mathrm{F}: \quad<\text { FAM>GCCTCCTTTAGTTCCTGCAC } \\
\mathrm{R}: \text { AGCATCGGACTTTCCAGGT }\end{array}$ & 60 & $137-167$ & 19 & 2 & $0.512 *$ & 0.947 & 18 & 3 & $0.538^{*}$ & 0.944 \\
\hline $\mathrm{Aac0} 4$ & GF111930 & $(\mathrm{GT})_{7}(\mathrm{GA})_{16}$ & $\begin{array}{l}\mathrm{F}: \quad<\text { FAM>GCATTGTCATCTGCAACCAC } \\
\mathrm{R}: \text { GCAGGGGCCATAAGTCATAA }\end{array}$ & 60 & $212-242$ & 20 & 6 & 0.824 & 0.750 & 20 & 6 & 0.794 & 0.800 \\
\hline Aac05 & GF111931 & $(\text { TACGCT })_{2}$ & $\begin{array}{l}\text { F }: \quad<\text { FAM>GTCCAATTCAGCTCGGCTT } \\
\text { R: }\end{array}$ & 62 & 396 & 15 & 1 & - & - & 19 & 1 & - & - \\
\hline $\mathrm{Aac} 06$ & GF111932 & $(\mathrm{TC})_{19}(\mathrm{AC})_{8}$ & $\begin{array}{l}\text { F: } \quad<\text { FAM>TCTGATCCATCTGGTTGTCTAA } \\
\text { R: TGCATGGTGCTAGAGTAATCC }\end{array}$ & 64 & $132-192$ & 20 & 5 & $0.522 *$ & 0.050 & 19 & 8 & $0.859^{*}$ & 0.000 \\
\hline Aac07 & GF111933 & $(\mathrm{GT})_{6}$ & $\begin{array}{l}\mathrm{F}: \text { <NED>ACTTGTTGCTGATACGCACG } \\
\mathrm{R}: \text { ACCTGGGGATGATGGTAGC }\end{array}$ & 59 & $202-222$ & 20 & 3 & 0.655 & 0.600 & 17 & 3 & 0.643 & 0.824 \\
\hline $\mathrm{Aac} 08$ & GF111934 & $(\mathrm{CA})_{11}$ & $\begin{array}{l}\mathrm{F}: \quad<\text { NED>CGCACGTACACACACACACAT } \\
\mathrm{R}: \text { TCAGCCAGTTACACTTCTGTGG }\end{array}$ & 57 & 245 & 18 & 1 & - & - & 17 & 1 & - & - \\
\hline Aac09 & GF111935 & $(\mathrm{CT})_{18}$ & $\begin{array}{l}\mathrm{F}: \quad<\text { NED>CAAGCGCCTCCAAGGTAGAT } \\
\mathrm{R}: \text { GGAAAGAGAAGCAAGGAGTGG }\end{array}$ & 66 & $302-352$ & 18 & 7 & 0.674 & 0.556 & 20 & 7 & 0.762 & 0.650 \\
\hline Aac10 & GF111936 & $(\mathrm{CT})_{7}$ & $\begin{array}{l}\mathrm{F}: \quad<\text { NED>AGCCGTGAGTGAACTGCTTT } \\
\mathrm{R}: \text { AAGCCCAAACTTCTTCCTCG }\end{array}$ & 60 & $112-128$ & 20 & 2 & $0.512 *$ & 0.950 & 20 & 2 & $0.501^{*}$ & 0.850 \\
\hline Aac11 & GF111937 & $(\mathrm{AC})_{5}$ & $\begin{array}{ll}\mathrm{F}: & <\text { FAM }>\text { AAAGGAACAACCCAAGAGGG } \\
\mathrm{R}: & \text { TGGGGAGTGGACGTAAGTGT }\end{array}$ & 60 & $202-228$ & 20 & 2 & 0.142 & 0.150 & 19 & 1 & 0.000 & 0.000 \\
\hline Aac12 & GF111938 & $\begin{array}{l}(\mathrm{GC})_{5}(\mathrm{AC})_{3} \\
\quad \mathrm{AAAC}(\mathrm{AG})_{17}\end{array}$ & $\begin{array}{l}\mathrm{F}: \quad<\text { NED>GCTCTGTAATCTCGGCTTCCT } \\
\mathrm{R}: \text { TCCAGTTCAAGCTCTCTCAGC }\end{array}$ & 60 & $167-181$ & 19 & 5 & 0.688 & 0.974 & 20 & 3 & $0.621^{*}$ & 0.950 \\
\hline Aac13 & GF111939 & $(\mathrm{CA})_{7}$ & $\begin{array}{ll}\mathrm{F}: & <\text { FAM>CTAGACAACCCAAGAGAGGGG } \\
\mathrm{R}: & \text { TTGGAGAGTGGATGTAGGTGC }\end{array}$ & 60 & $182-202$ & 19 & 1 & 0.000 & 0.000 & 20 & 3 & $0.347 *$ & 0.150 \\
\hline Aac14 & GF111940 & $\begin{array}{l}(\mathrm{CA})_{6}(\mathrm{CG})_{7} \\
\quad(\mathrm{CA})_{11}(\mathrm{GA})_{11}\end{array}$ & $\begin{array}{l}\mathrm{F}: \quad<\text { FAM }>\text { GGCCAGTTGTGTTGATGAAA } \\
\mathrm{R}: \text { TTAAGCCCCTGGTGAAAACA }\end{array}$ & 55 & $377-392$ & 18 & 4 & 0.668 & 0.556 & 16 & 5 & 0.764 & 0.750 \\
\hline
\end{tabular}

Note $:-=$ monomorphic loci; $A=$ number of alleles per locus; $H_{\mathrm{e}}=$ expected heterozygosity; $H_{\mathrm{o}}=$ observed heterozygosity; $N=$ number of individuals; $T_{\mathrm{a}}=$ annealing temperature.

* Deviation from Hardy-Weinberg equilibrium exact test $(P<0.000416$, after standard Bonferroni correction).

${ }^{a}$ The M13 label primer is given in brackets with each forward primer.

${ }^{\mathrm{b}}$ Geographical coordinates for the studied populations: Manaus, Amazonas, Brazil (03ํำ $\left.07.17^{\prime \prime} \mathrm{S}, 59^{\circ} 58^{\prime} 53.10^{\prime \prime} \mathrm{W}\right)$; Manicoré, Amazonas, Brazil $\left(05^{\circ} 49^{\prime} 30.05^{\prime \prime} \mathrm{S}, 61^{\circ} 16^{\prime} 16.12^{\prime \prime} \mathrm{W}\right)$. 
TABLE 2. Transspecies amplification of 14 microsatellite markers developed for Astrocaryum aculeatum.

\begin{tabular}{|c|c|c|c|c|c|c|c|c|c|c|c|c|}
\hline \multirow[b]{2}{*}{ Locus $^{\mathrm{a}}$} & \multicolumn{2}{|c|}{ A. acaule Mart. ${ }^{\mathrm{b}}$} & \multicolumn{2}{|c|}{ A. jauari Mart. ${ }^{\mathrm{c}}$} & \multicolumn{2}{|c|}{ A. mигитиги Mart. ${ }^{\mathrm{d}}$} & \multicolumn{2}{|c|}{ A. vulgare Mart. ${ }^{\mathrm{e}}$} & \multicolumn{2}{|c|}{$\begin{array}{l}\text { Bactris gasipaes } \\
\text { Kunth }^{\mathrm{f}}\end{array}$} & \multicolumn{2}{|c|}{$\begin{array}{c}\text { Euterpe precatoria } \\
\text { Mart. } \mathrm{g}\end{array}$} \\
\hline & Allele range (bp) & $A$ & Allele range (bp) & $A$ & Allele range (bp) & $A$ & Allele range (bp) & $\bar{A}$ & Allele range (bp) & $\bar{A}$ & Allele range (bp) & $A$ \\
\hline $\mathrm{Aac} 01$ & 338 & 1 & 338 & 1 & 338 & 1 & 338 & 1 & 338 & 1 & 338 & 1 \\
\hline $\mathrm{Aac} 02$ & 291 & 1 & 291 & 1 & 291 & 1 & 291 & 1 & 291 & 1 & 291 & 1 \\
\hline $\mathrm{Aac} 03$ & 145 & 1 & $127-147$ & 2 & 145 & 1 & 145 & 1 & 145 & 1 & 145 & 1 \\
\hline Aac04 & 223 & 1 & $197-207$ & 2 & $207-227$ & 4 & $187-207$ & 2 & NA & NA & 187 & 1 \\
\hline $\mathrm{Aac} 05$ & $392-457$ & 2 & $322-362$ & 3 & 453 & 1 & $392-457$ & 2 & NA & NA & NA & NA \\
\hline Aac06 & 154 & 1 & 134 & 1 & $142-162$ & 5 & $142-162$ & 2 & NA & NA & NA & NA \\
\hline Aac07 & $207-217$ & 2 & $207-217$ & 3 & $212-227$ & 2 & NA & NA & NA & NA & NA & NA \\
\hline Aac08 & NA & NA & NA & NA & NA & NA & NA & NA & NA & NA & NA & NA \\
\hline Aac09 & NA & NA & $322-327$ & 2 & 329 & 1 & 323 & 1 & NA & NA & NA & NA \\
\hline Aac10 & $112-128$ & 2 & $97-117$ & 2 & $108-132$ & 2 & 114 & 1 & 114 & 1 & 112 & 1 \\
\hline Aac11 & 205 & 1 & 205 & 1 & 205 & 1 & 205 & 1 & $192-222$ & 2 & $202-228$ & 2 \\
\hline Aac12 & $152-202$ & 2 & $175-182$ & 5 & $158-178$ & 4 & $162-178$ & 2 & $147-173$ & 3 & 151 & 1 \\
\hline Aac13 & $182-212$ & 2 & $182-212$ & 2 & $182-206$ & 2 & $182-212$ & 2 & $192-222$ & 3 & NA & NA \\
\hline Aac14 & $372-382$ & 2 & $382-392$ & 2 & NA & NA & $382-398$ & 2 & NA & NA & NA & NA \\
\hline
\end{tabular}

Note: $A=$ number of alleles; $\mathrm{NA}=$ no amplification.

a PCR annealing temperature as in Table $1 ; N=4$ for all species.

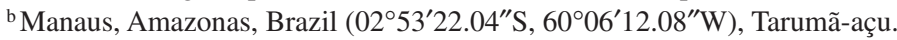

${ }^{\circ}$ Coari, Amazonas, Brazil (040'⒌ $\left.00^{\prime \prime} \mathrm{S}, 63^{\circ} 25^{\prime} 22.00^{\prime \prime} \mathrm{W}\right)$, Santa Luzia do Buiçuzinho.

${ }^{\mathrm{d}}$ Coari, Amazonas, Brazil $\left(04^{\circ} 01^{\prime} 03.67^{\prime \prime} \mathrm{S}, 63^{\circ} 25^{\prime} 17.41^{\prime \prime} \mathrm{W}\right)$, Santa Luzia do Buiçuzinho.

${ }^{\mathrm{e}}$ Manaus, Amazonas, Brazil (0253’37.40”S, 5958'23.50”W), Embrapa Amazônia Ocidental.

${ }^{\mathrm{f}}$ Manaus, Amazonas, Brazil (0253’31.00”S, 5958'21.70”W), Embrapa Amazônia Ocidental.

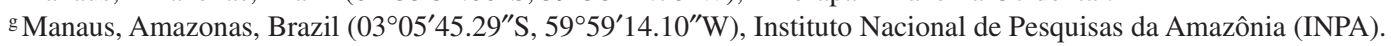

and along the Madeira River in a forest near the city of Manicoré. These populations are part of an EMBRAPA-CPAA program for in situ conservation of genetic resources.

The descriptive statistics and the test for Hardy-Weinberg equilibrium (HWE) were inferred using Genetic Data Analysis (GDA) (Lewis and Zaykin, 2000). Twelve microsatellite loci were polymorphic and two loci were monomorphic for both populations (Table 1). The Manaus population presented one to seven alleles per locus (average: 3.4 ), observed heterozygosity ranging from 0 to 0.974 (average: 0.498 ), and expected heterozygosity ranging from 0 to 0.824 (average: 0.467 ). The Manicoré population showed one to eight alleles per locus (average: 3.7), observed heterozygosity ranging from 0 to 0.950 (average: 0.556 ), and expected heterozygosity ranging from 0 to 0.859 (average: 0.526). Higher values were found for the Manicoré population possibly because this population is larger and more continuous, whereas the Manaus population is found in a forest fragment. For most loci in each population, observed heterozygosity was higher than expected heterozygosity.

Fourteen microsatellite loci were tested for cross amplification in four other Astrocaryum species and two species of Arecaceae $(N=4)$. The amplification rate ranged from $50 \%$ to $93 \%$; among the tested species, polymorphism ranged from a minimum of one polymorphic locus in Euterpe precatoria Mart. and a maximum of nine polymorphic loci in A. jauari Mart. (Table 2).

The low level of polymorphism is most likely due to the small number of repetitions found at some loci. Additionally, four microsatellites were hexanucleotides, which show lower levels of polymorphism than dinucleotides due to lower mutation rates. These results are likely a consequence of the random mating system (Ramos et al., 2011).

\section{CONCLUSIONS}

The 14 microsatellites reported provide tools for further studies in population genetics, which play a critical role in increasing the knowledge of the genetic diversity of the available germplasm of A. aculeatum in the Amazon forest, and also allow the development of management and conservation policies for this species in the Amazon. This highly informative new set of markers provides invaluable support to molecular mapping, genetic diversity, and mating system analyses to aid in the genetic improvement and conservation of tucumã.

\section{LITERATURE CITED}

Billotte, N., P. J. L. Lagoda, A. M. Risterucci, and F. C. Baurens. 1999. Microsatellite-enriched libraries: Applied methodology for the development of SSR markers in tropical crops. Fruits 54: $277-288$.

Doyle, J. J., And J. L. Doyle. 1990. A rapid total DNA preparation procedure for fresh plant tissue. Focus (San Francisco, Calif.) 12: $13-15$.

HaLl, T. A. 1999. BioEdit: A user-friendly biological sequence alignment editor and analysis program for Windows 95/98/NT. Nucleic Acids Symposium Series 41: 95-98.

Lewis, P. O., AND D. Zaykin. 2000. Genetic data analysis: Computer program for the analysis of allelic data. Version 1.0 (d15). Free program distributed by the authors over the internet from the GDA. Available at: http://www.eeb.uconn.edu/people/plewis/software.php.

Lopes, M. T. G., J. L. V. De Macêdo, R. Lopes, J. Van Leeuwen, S. L. F. Ramos, and L. G. Bernardes. 2012. Domestication and breeding of the tucumã palm. In A. Borém, M. T. G. Lopes, C. R. Clement, and H. Noda [eds.], Domestication and breeding: Amazonian species, 421436. Universidade Federal de Viçosa, Viçosa, Minas Gerais, Brazil.

Martins, W. S., D. C. S. Lucas, K. F. De Souza Neves, and D. J. Bertioli. 2009. WebSat: A web software for microsatellite marker development. Bioinformation 3: 282-283.

Ouborg, N. J., C. Pertoldi, V. Loeschcke, R. Bijlsma, and P. W. HEDRICK. 2010. Conservation genetics in transition to conservation genomics. Trends in Genetics 26: 177-187.

Ramos, S. L. F., M. T. G. Lopes, R. Lopes, R. N. V. da Cunha, J. L. V. de Macêdo, L. A. S. Contim, C. R. Clement, et Al. 2011. Determination of the mating system of Tucumã palm using microsatellite markers. Crop Breeding \& Applied Biotechnology 11: $181-185$.

Schroth, G., M. S. S. Mota, R. Lopes, and A. F. Freitas. 2004. Extractive use, management and in situ domestication of a weedy palm, Astrocaryum tucuma, in the Central Amazon. Forest Ecology and Management 202: 161-179.

SChUelKe, M. 2000. An economic method for the fluorescent labeling of PCR fragments. Nature Biotechnology 18: 233-234. 